\title{
PENERAPAN MODEL PEMBELAJARAN EXAMPLE NON EXAMPLE UNTUK MENINGKATKAN HASIL BELAJAR GULING DEPAN TUNGKAI BENGKOK
}

\author{
Gilang Abdi Wisnu Pradana ${ }^{(1)}$, Agus Margono ${ }^{(2)}$ \\ (1) (2) Universitas Sebelas Maret Surakarta
}

\begin{abstract}
The purpose of this study is to improve the student's achievement in gymnastic floor of crooked legs forward rolling in X-4 Senior High School Kebakkramat in academic year 2016/2017.

This research is classroom action research that was done in two cycles, each cycles consist of two meetings. Subject of this research is the students of X-4 grade that consisted of 36 students. The data's source collecting from the students, teachers, and the researcher. Techniques of data's collection used test and observation. Data validity using data triangulation technique. Data analysis using qualitative descriptive analysis technique with percentage technique.

The result of data analysis showed there is improvement of student's learning outcomes in gymnastic floor of crooked legs forward rolling. In pracycles the precentage of the completness is $41,67 \%$ or 15 students, not completed yet $58,33 \%$ or 21 students. In first cycles the precentage of the completness is $63,88 \%$ or 23 students, not completed yet $36,11 \%$ or 13 students. In second cycles the percentage of the completness is $83,33 \%$ or 30 students, not completed yet $16,66 \%$ or 6 students. The learning result of gymnastic floor crooked legs of forward rolling has been reached according the expectation in second cycles with minimum criteria 75

Based on result analysis above we get the conclusion that the implementation of example non example improved the result learning of forward rolling of crooked legs in students of Senior High School Kebakkramat academic year 2016/2017.
\end{abstract}

Keywords : Learning outcomes, crooked legs of forward rolling, implementation of example non example learning model 


\section{PENDAHULUAN}

Pendidikan jasmani merupakan bagian dari pendidikan secara umum. Pendidikan jasmani memiliki fungsi membina gerak fisisk agar tercapai suatu tujuan pendidikan. Manfaat dari pendidikan jasmani diantaranya mendukung perkembangan dan kemampuan peserta didik baik fisik, gerak, mental, sosial dan emosional. Diharpakan setelah tercapainya tujuan pendidikan peserta didik mampu menerapkan nilai - nilai yang terkandung dalam pendidikan jasmani itu sendiri.

Senam lantai merupakan salah satu cabang yang diajarkan pada siswa Sekolah Menengah Atas (SMA). Standar kompetensi senam mempraktikkan keterampilan rangkaian senam lantai dan nilai-nilai yang terkandung didalamnya. Serta kompetensi dasar senam yaitu mempraktikan rangkain senam lantai dengan menggunakan bantuan serta nilai percaya diri, kerjasama, tanggung jawab dan menghargai teman. Mempraktikkan rangkaian senam lantai tanpa alat serta nilai percaya diri, kerjasama dan tanggungjawab. Maka dengan demikian senam lantai harus diajarkan kepada peserta didik dengan baik dan benar supaya mendapatkan hasil yang optimal.

Banyak faktor yang menjadi penghambat proses pembelajaran senam lantai, lebih dari $70 \%$ siswa pada materi guling depan Kelas X-4 SMA Negeri Kebakkramat tahun ajaran 2016/2017 belum dapat mencapai target yang telah ditentukan. Hambatan tersebut berupa siswa takut untuk melakukan gerakan mengguling, pada saat menaruh tengkuk pada matras, serta posisi kedua telapak kaki, lutut tidak dirapatkan, dan posisi gerakan saat menggulingkan badan masih kaku tidak ada kehalusan gerak, sehingga pada saat sikap akhir dari pada gerakan mengguling siswa masih kurang bisa menyeimbangkan tubuhnya. Maka dengan demikian nilai yang diperoleh siswa masih kurang dari KKM yang ditentukan serta didominasi oleh siswa putri, KKM minimal sekolah SMA Negeri Kebakkramat yakni 75. 
Hal-hal yang menjadi penghambat siswa pada saat pembelajaran guling depan ditemukan saat observasi di sekolah SMA Negeri Kebakkramat pada waktu PPL (Program Pengalaman Lapangan). Kesulitan siswa muncul dikarenakan guru memberikan pembelajaran yang masih konvensional, sehingga pembelajaran hanya bersifat satu arah dan dominan dengan model pembelajaran komando, sehingga siswa kurang begitu memahami maupun kurang tertarik terhadap pembelajaran yang disajikan oleh guru.

Banyak metode pembelajaran yang dapat diterapkan oleh guru penjaskes agar memperolah hasil yang maksimal atas pembelajaran yang telah dilaksanakan. Metode pembelajaran tersebut harus sesuai dengan kesulitan siswa dan karakter siswa dalam kelas tersebut. Dengan demikian, perlu diterapkannya metode pembelajaran Example Non Example, yang nantinya pada waktu pelaksanaan pembelajaran dapat meningkatkan hasil belajar siswa pada ranah kognitif, psikomotor, dan psikomotor
Model pembelajaran example non example, membelajarkan siswa untuk menganalisis suatu konsep dari gambar yang disajikan oleh guru. Guru menyajikan gambar sesuai konsep yang benar dan menyajikan gambar yang tidak sesui konsep pembelajaran yang benar. Selain itu, juga dapat membelajarkan kepekaan siswa terhadap masalah dalam pembelajaran. Model pembelajaran yang digunakan harus disesuaikan dengan karakter siswa pada kelas tersebut. Karakter siswa pada kelas tersebut, siswa pada saat pembelajaran kurang memperhatikan, serta siswa lebih menyukai berkumpul dengan teman temannya, sehingga ketertarikan siswa berkurang

Pembelajaran example non example menitik beratkan pada analisis siswa terhadap suatu permasalahan yang dapat berupa kesulitan siswa dalam menerima pelajaran. Disajikan melalui media gambar ataupun melalui tampilan di LCD proyektor semenarik mungkin agar siswa dapat fokus dalam pembelajaran yang disajikan oleh guru. Siswa dibagi menjadi 
kelompok-kelompok kecil, kemudian didiskusikan selanjutnya dipresentasikan. Siswa yang lain boleh menanggapi apa yang dipaparkan oleh siswa yang telah mempresentasikan.

\section{METODE PENELITIAN}

Metode penelitian yang

digunakan adalah Penelitian

Tindakan Kelas.

Subjek yang diteliti dalam Penelitian Tindakan Kelas (PTK) ini adalah semua siswa kelas X-4 SMA Negeri Kebakkramat tahun ajaran 2016/2017, dengan jumlah 36 siswa.

Teknik pengumpulan data dalam Penelitian Tindakan Kelas ini terdiri atas: tes dan observasi. Tes dipergunakan untuk mendapatkan data tentang hasil belajar guling depan tungkai bengkok yang dilakukan oleh siswa..

Observasi, digunakan sebagai teknik untuk mengumpulkan data tentang aktivitas siswa dan guru selama kegiatan pembelajaran.

\section{HASIL DAN PEMBAHASAN}

Hasil belajar siswa dalam pembelajaran guling depan tungkai bengkok setelah tindakan siklus II dilakukan menunjukkan hasil bahwa yang mencapai kriteria ketuntasan yaitu $83,33 \%$ atau 30 siswa. Sesuai dengan KKM sekolah untuk pendidikan Jasmani di SMA Negeri Kebakkramat yaitu 75. Dalam hal ini sejumlah 30 siswa telah masuk dalam kriteria Tuntas sedangkan 6 siswa Belum Tuntas.

Berdasarkan hasil pelaksanaan tindakan pada Siklus I dan II dapat disimpulkan bahwa Terjadi Peningkatan Hasil Belajar Senam Lantai Guling Depan Tungkai Bengkok pada siswa kelas X-4 SMANegeri Kebakkramat tahun ajaran 2016/2017. Dari hasil analisis yang diperoleh peningkatan yang signifikan terjadi pada Pra Tindakan ke Siklus I dan dari Siklus I ke Siklus II. Pada pratindakan hasil belajar guling depan tungkai bengkok dengan presentase ketuntasan $41,67 \%$ atau 15 siswa sedangkan yang belum tuntas $58,33 \%$ atau 21 siswa, dengan kategori kurang sebanyak 58,33\% atau 21 siswa, kategori cukup sebanyak 36,11\% atau 13 siswa, dan kategori baik sebanyak $5,56 \%$ atau 2 siswa. 
Peningkatan terjadi pada Siklus I dan Siklus II setelah dilakukan perapan model pembelajaran example non example. Hasil belajar guling depan tungkai bengkok meningkat menjadi lebih baik meskipun belum optimal.

Pada pelaksanaan siklus I dengan menggunakan model pembalajaran example non example pada materi senam lantai guling depan tungkai bengkok merupakan tindak lanjut dari permasalahn pembelajaran pada saat belum diberikan penerapan tindakan pada siswa Kelas X-4 SMA Negeri Kebakkramata Tahun Ajaran 2016/2017. Melalui permasalahan tersebut guru dan peneliti melakukan diskusi untuk mencari solusi untuk meningkatkan hasil belajar. Pada siklus I dilihat dari hasil pembelajaran senam lantai guling depan tungkai bengkok sudah menunjukkan peningkatan dari data awal pratindakan, dengan presntase ketuntasan $23 \%$ atau 23 siswa, sedangkan yang belum tuntas $36,11 \%$ atau 13 siswa. Pada siklus II terjadi peningkatan yang lebih baik lagi dikarenakan kaektifan siswa, hasil analisa siswa, serta kondisi kelas yang lebih kondusif dari siklus sebelumnya. Peningkatan hasil belajar siswa yang tuntas sebanyak $83,33 \%$ atau 30 siswa, sedangkan yang belum tuntas sebanyak $16,66 \%$ atau 6 siswa dari jumlah keseluruhan 36 siswa.

Kesimpulan dari penerapan model pembelajaran example non exmpale mampu meningkatkan hasil belajar siswa dari segi kognitif, psikomotor dan afektif pada siswa kelas X-4 SMA Negeri Kebakkaramat Tahun Jaran 2016. Minimnya sarana dan prasarana serta belum adanya kreativitas guru penjasorkes dalam memodifkasi alat pembelajaran. Dikarenakan guru hanya memanfaatkan media pembelajaran yang ada tanpa adanya upaya untuk menggunakan alat bantu pembelajaran, sehingga banyak siswa yang merasa jenuh, mudah bosan, kesulitan ketika proses belajar mengajar sedang berlangsung.

\section{SIMPULAN DAN SARAN}

\section{Simpulan}

Penelitian Tindakan Kelas pada siswa kelas X-4 SMA Negeri Kebakkramat tahun Ajaran 2016/2017 dilaksanakan dalam dua 
Siklus. Setiap siklus terdiri atas empat tahapan, yaitu:

Perencanaan, (2) Pelaksanaan

Tindakan, (3) Observasi dan

Interpretasi dan (4) Analisis dan

Refleksi. Pelaksanaan setiap siklus terdiri dari 2 kali pertemuan. Berdasarkan analisis data yang telah dilakukan, diperoleh hasil sebagai berikut :

Hasil analisis data menunjukkan adanya peningkatkan hasil belajar senam lantai guling depan tungkai bengkok dari Prasiklus ke Siklus I dan dari Siklus I ke Siklus II. Hal ini dapat dilihat dari pencapaian hasil belajar pada Pratindakan hasil belajar senam lantai guling depan tungkai bengkok pada persentase tuntas $38,89 \%$ atau 14 siswa dan $61,11 \%$ atau 22 siswa yang belum tuntas dari jumlah keseluruhan siswa sebanyak 36. Pada Siklus I hasil belajar senam lantai guling depan tungkai bengkok pada persentase tuntas $63,89 \%$ atau 23 dan 36,11\% atau 13 siswa yang belum tuntas dari jumlah keseuluruhan siswa 36. Sedangkan pada Siklus II hasil belajar senam lantai guling depan tungkai bengkok pada persentase tuntas $83,33 \%$ atau
30 siswa dan $16,67 \%$ atau 6 siswa yang belum tuntas dari jumlah keseluruhan 36 siswa dengan KKM 75

Berdasarkan hasil analisis diatas maka dapat disimpulkan bahwa penerepan model pembelajaran example non example dapat meningkatkan hasil belajar guling depan tungkai bengkok pada siswa kelas X-4 SMA Negeri Kebakkramat tahun ajaran 2016/2017.

\section{Saran}

Berdasarkan hasil penelitian tindakan kelas ini, maka dapat disarankan beberapa hal yakni sebagai berikut :

1. Hendaknya guru lebih sering untuk menerapkan model pembelajaran terbaru yang sesui dengan kondusi kelas tidak hanya menggunakan model pembelajaran yang bersifat konvensional. Hal tersebut dapat membantu dalam penyampaian materi dan pengelolaan kelas.

2. Pembelajaran menggunakan Model Pembelajaran example non example dalam pembelajaran Penjasorkes dapat meningkatkan hasil belajar senam lantai guling 
depan tungkai bengkoki, guru hendaknya mencoba model pembelajaran pembelajaran tersebut.

3. Siswa yang belum memenuhi kriteria ketuntasan dalam pembelajaran senam lantai guling depan tungkai bengkok akan didakan remidial teaching yang bertujuan agar siswa dapat memenuhi kriteria ketuntasan niali secara maksimal.

4. Kepada calon peneliti untuk dapat lebih mengembangkan model pembelajaran example non example dengan memilih cabang olahraga yang lain. 


\section{DAFTAR PUSTAKA}

Aunurahman, (2013). Belajar dan Pembelajara. Bandung: Alfabeta.

Deni Kurniawan, (2014). Pembelajaran Terpadu Tematik (Teori, Praktik, dan Penilaian). Bandung : Alfabeta.

Dimyati \& Mudjiono, (2013). Belajar dan Pembelajaran. Jakarta: Rineka Cipta

Djamarah, Syaiful Bahri \& Aswan Zain, (2010). Strategi Belajar Mengajar. Jakarta: Rineka Cipta.

Dini Rosdiani, (2012). Dinamika Olahraga dan Pengembangan Nilai, Bandung: Alfabeta.

Dini Rosdiani, (2014). Perencanaan Pembelajaran Dalam Pendidikan Jamani dan Kesehatan, Bandung: Alfabeta

Hustadarta. \& Saputra, Y. M. (2010). Belajar dan Pembelajaran Pendidikan Jasmanni. Bandung: Alfabeta.

Imas Kurniasih \& Berlin Sani, (2016). Ragam Pengembangan Model Pembelajaran untuk Penbingkatan Profresionalitas Guru. Yogyakarta: Kata Pena.

Komarudin. (2013). Psikologi Olahraga. Bandung: PT Remaja Rosdakarya.

Mia Kusumawati, (2015). Penelitian Pedidikan Penjasorkes. Bandung: Alfabeta.

Ngadiyanto, (2016). Peningkatan Kemampuan Mempraktikan Senam Lantai Guling Depan Melalui Pendekatan Permainan. Jurnal Penenlitian Tindakan Kelas, 17 (1), 26

Saefuddin, A. \& Berdiati, I. (2014). Pembelajaran Efektif. Bandung: PT Remaja Rosdakarya

Susanto. \& Ahmad. (2013). Teori Belajar Pembelajaran di Sekolah Dasar. Jakarta: Prenadia Media Group 